\title{
BMJ Open Perspectives on Spain's legislative experience providing access to healthcare to irregular migrants: a qualitative interview study
}

\author{
Renee Y Hsia (1) , 1,2 Diana Gil-González ${ }^{3,4}$
}

To cite: Hsia RY, Gil-González D. Perspectives on Spain's legislative experience providing access to healthcare to irregular migrants: a qualitative interview study. BMJ Open 2021;11:e050204. doi:10.1136/ bmjopen-2021-050204

- Prepublication history and additional supplemental material for this paper are available online. To view these files, please visit the journal online (http://dx.doi.org/10.1136/ bmjopen-2021-050204).

Received 16 February 2021 Accepted 09 August 2021

D Check for updates

C Author(s) (or their employer(s)) 2021. Re-use permitted under CC BY-NC. No commercial re-use. See rights and permissions. Published by BMJ.

1Department of Emergency Medicine, University of California San Francisco, San Francisco, California, USA

${ }^{2}$ University of California, San Francisco, Philip R Lee Institute for Health Policy Studies, San Francisco, California, USA ${ }^{3}$ Department of Community Nursing, Preventive Medicine and Public Health, and History of Science, University of Alicante, Alicante, Spain

${ }^{4}$ CIBER Epidemiología y Salud Pública (CIBERESP), Madrid, Spain

Correspondence to Dr Renee Y Hsia; renee.hsia@ucsf.edu

\section{ABSTRACT}

Objectives In 2018, Spain adopted a national law that significantly expanded healthcare access to all residents, including undocumented migrants. This was a substantial shift from a more restrictive system of coverage in previous years. However, irregular migrants continue to experience challenges accessing healthcare in Spain. This study aimed to describe the legislative and administrative barriers to implementation of this law from the perspective of providers and administrators of the healthcare system.

Design We interviewed 12 individuals using a semistructured format.

Setting Spain.

Participants 12 participants were interviewed; 7 males, 5 females. Participants included Spanish healthcare workers, government officials, hospital administrators, individuals working with non-governmental organisations focused on the provision of healthcare, and experts studying healthcare for underserved populations.

Primary and secondary outcome measures Interviews delved into personal experiences and knowledge of the entitlements and barriers of providing or trying to access care for undocumented migrants.

Results The interviews yielded eight key themes: (1) context of universal healthcare in Spain pre2012; (2) erosion of trust as rationale for more restrictive policies of 2012; (3) challenges of the 3-month residency requirement; (4) areas of ambiguity: exceptions in the 2012 Royal Decree Law not discussed in the 2018 Royal Decree Law; (5) jurisdictional authority and conflicts between national and $\mathrm{AC}$ government; (6) near impossibility of obtaining documentation for exportation of healthcare; (7) difficulties obtaining necessary paperwork to register residency; and (8) rise of NGOs to provide support to irregular migrants.

Conclusion While there has been a general political movement to expand healthcare access for undocumented migrants in Spain, there remains a fundamental need to clarify the legal entitlements for undocumented migrants nationally and create administrative consistency across autonomous communities for providing health cards for undocumented migrants. Other countries may be able to draw lessons from the Spanish experience about the legislative frameworks surrounding access to healthcare for undocumented migrants.

\section{Strengths and limitations of this study}

- This qualitative study used 12 in-depth interviews to provide a unique perspective about barriers to practical application of the 2018 Royal Decree Law through the eyes of providers and administrators of the healthcare system who interact most with undocumented migrants, complementing the findings of quantitative studies.

- This study established a historical trend in which Spanish policies became more restrictive, and, later, more progressive, but the previous law's lingering barriers were difficult to change, even with the establishment of more progressive policy.

- The findings suggest that ambiguities in the 2018 Royal Decree Law exacerbated the administrative differences in application of the national law and produced even greater departures from the legislation.

- The study sample comprised healthcare workers and other individuals working in Spain, and the results may not be generalisable to other European countries.

\section{INTRODUCTION}

Globally, irregular (or 'undocumented') migrants generally hold an uncertain legal status with few entitlements in their host countries, especially when taking into account national and supranational legislative frameworks. While displaced migrants are not a new phenomenon, the influx of new arrivals in the European Union (EU) and the US has been a source of increasing concern for how host countries can meet migrants' most basic needs, including healthcare.

Despite numerous resolutions on the importance of the provision of healthcare to migrants and displaced persons from the European Parliament, ${ }^{12}$ there is a heterogeneity of legal frameworks surrounding the provision of this care. Countries that have signed onto the United Nations International Covenant on Economic, Social and Cultural 
Rights, ${ }^{3}$ and more specifically, Charter of Fundamental Rights of the EU, ${ }^{4}$ may not share the same understanding of these frameworks, causing variable implementation of healthcare delivery. The European Union Agency for Fundamental Rights has already published a review of healthcare entitlements of migrants in an irregular situation (a.k.a., 'irregular migrants') in the 27 member states of the EU. ${ }^{5}$ However, there is less literature describing the range of policies that have been implemented at a local level to support these frameworks or how these resolutions have translated into care for migrants on the ground.

Of the policies that do exist, many are centred around the initial phase of treating migrants' health issues, such as infectious diseases, public health screenings, and vaccinations, rather than how displaced migrants can access healthcare from public systems once they are resettled. ${ }^{6}$ For example, the first WHO toolkit developed to aid countries in analysing and strengthening their health capacity and migrant response only concentrates on the initial phase of influx and does not take into consideration the evolving needs of migrants after this initial stage of arrival. ${ }^{8}$

This paper expands on the assessment of policies and health system capacities to account for the postarrival and permanent accommodation periods needed to address the health aspects of migration in the country of Spain, which has experienced a sharp increase in the number of migrants (both documented and undocumented) over the past few years. ${ }^{9}{ }^{10}$ Many migrants are now choosing Spain as an alternate gateway to Europe given the recent deals to shut routes and restrict migration to Italy and Greece. ${ }^{11}$ Migrants whose requests for asylum in Spain are denied find themselves in a vulnerable administrative situation. These irregular migrants have an uncertain legal status in the country which may jeopardise their ability to apply for work permits, housing, and social programmes such as education and healthcare. ${ }^{12} 13$ There has also been a significant shift in government policy, from one of exclusivity as seen in the Royal Decree Law in 2012 (RDL $16 / 2012$ ) to one that most recently has promulgated free access beyond emergency care to primary care to all, regardless of immigration or citizenship status. ${ }^{14}$ This momentous change in Spain's national policy provides an ideal platform to study how policies to include undocumented migrants into the healthcare system have been incorporated, as well as unforeseen barriers that have arisen. The overall aim of this study was to better understand the legislative and administrative challenges to practical implementation of the more universal policy of the 2018 Royal Decree Law to expand healthcare access to undocumented migrants in Spain.

\section{METHODS}

\section{Study setting}

Spain's form of government is a parliamentary monarchy, or sometimes also called a constitutional monarchy, a representative system in which the king exercises the function of head of state under the control of the legislative power (parliament) and the executive power (government). The country is organised into 17 autonomous communities, which in turn are comprised of 50 provinces and 2 autonomous cities, that are given legislative/jurisdictional powers over regional institutions, urban planning and public works, internal transportation networks, environmental management, cultural and recreational institutions, and economic development. ${ }^{15}$ Spain has a tax-based system of healthcare where a nearuniversal public health system provides coverage to $99.1 \%$ of the population with entitlement based on social security working status and divided into four broad categories: active, pensioner, subsidised employee, and unemployed with no remaining subsidies. Under current guidelines, undocumented immigrants, who from 2012 to 2018 were eligible for only emergency care and obstetric and paediatric services, are entitled to full benefits under Spanish law. ${ }^{16}$ It is considered one of the most advanced systems of healthcare in the world, with an amenable mortality rate of 65.8 and preventable mortality rate of 45.4 , both far below the EU averages of 125 and 60.9 , respectively. ${ }^{16}$ As of 2019, life expectancy at birth is the highest of any European nation at 83.59 years. ${ }^{17}$ Despite significant cuts in tax revenues and health expenditures following the global recession of 2007-2009, health indices, including self-reported health status, have continued to improve and outperform EU averages.

With 168000 migrants making Spain their first country of arrival in Europe from 2015 to 2020, the estimated proportion of undocumented migrants ranks fourth in Europe but is more marked by the rate of increase, which has been accelerated by the clampdown on sea routes between North Africa and Italy. ${ }^{10}{ }^{18}{ }^{19}$ Italy, previously the most common entry point for undocumented migrants in Europe, has recently implemented stricter migration enforcement. This has significantly shifted migration patterns, with traffic via the Western Mediterranean route into Spain doubling from just under 10000 to 23000 in 2017 and doubling again to 57000 in 2018 even as overall undocumented migration to the EU has slowed. ${ }^{20}$

\section{Data collection techniques}

The interview guide (online supplemental table 1) was developed by both investigators after extensive literature review $^{1421-34}$ and input from experts in the field of public health and healthcare management with knowledge and experience in the issues of access to healthcare for immigrants, including undocumented migrants. Using standard methods, ${ }^{35-39}$ the interview explored several lines of inquiry, informed by reviewing the scientific and grey literature, as well as experience and knowledge of the research team. We did not include specific textual formulations and there was no predetermined sequential order or answer options. The interview guide was divided into four sections: an opening question regarding their professional background and role in the provision or 


\begin{tabular}{lllll}
\hline Table 1 & Participant profiles & & \\
\hline Code & Sex & Professional profile & Institution & Province \\
\hline 001 & M & Former physician \& government official & Ministry of Health & Valencia \\
002 & M & Academic researcher & University of Alicante & Alicante \\
003 & M & Professor \& former government official & Ministry of Health & National \\
004 & M & Administrator & Hospital Ramón y Cajal & Madrid \\
005 & M & Former physician \& Volunteer & NGO, Médicos del Mundo & Navarra \\
006 & M & Staff & NGO, REDER & Madrid, Valencia \\
007 & F & Physician \& volunteer & Government \& NGO, Yo Sí Sanidad Universal & Madrid \\
008 & F & Government official & Ministry of Health & Alicante \\
009 & F & Government official & Ministry of Health & Madrid \\
010 & M & Physician & Hospital Ramón y Cajal & Madrid \\
011 & F & Government official & Office of Immigration & Alicante \\
012 & F & Government official & Office of Immigration & Alicante \\
\hline
\end{tabular}

facilitation of healthcare for undocumented migrants; a second section comprised of their understanding of the steps required to receive healthcare as an undocumented migrant and the challenges faced by these patients, including the legislative and administrative hurdles; a third section about the differences in access faced by undocumented migrants compared with others in the healthcare system; and a closing question about any specific reflections or recommendations for how the system could be improved.

The participants for the Key Informant Interviews (KII) were selected using a snowball sampling method based on initial purposive sampling from study investigators. We contacted potential participants via electronic mail and/ or telephone to inform them of the basic premise of the study and request their participation. Respondents who were purposively sampled included public healthcare and benefits administrators, medical doctors ranging from general practitioners to subspecialists, hospital administrators, public health experts, academics working in the field of public health, and volunteers from nongovernmental and advocacy organisations working on issues of universal healthcare or healthcare for hard-toreach populations (table 1).

KIIs used a semistructured format and were $0.5-1.5$ hours in duration during the period of October 2019 to March 2020. These interviews delved into personal experiences and knowledge of the entitlements and barriers of providing or trying to access care for undocumented migrants. Our criteria for stopping recruitment of participants for the study was based on the concept of saturation, with a minimum of six interviews. We used the number of six interviews as the minimum based on prior work showing that 5-6 studies generally identify the majority of themes. ${ }^{40-42}$ We interviewed 12 individuals using the aforementioned semistructured format. Not every question on the interview guide was put forward to each participant, and when unanticipated topics arose, we sometimes posed additional questions to further explore those issues. Interviews were audio recorded (several were also video recorded) and conducted in Spanish.

\section{Data analysis}

Audio recordings were professionally transcribed verbatim in Spanish and checked for accuracy by the primary interviewer. All authors read all transcripts to obtain a common understanding of the content of each interview. Transcriptions were coded systematically with Atlas.ti. We performed a thematic analysis-'a method for identifying, analysing and reporting patterns (themes) within data ${ }^{43}$ - to ascertain key themes and combine findings across different informant groups. Authors then agreed on a set of codes to create an initial framework, and continued to refine codes by merging or disaggregating them based on re-reading data assigned to each category and comparing them with one another. This continued until no new codes were generated, and then the data were summarised into a matrix, which was then incorporated into a narrative to explain these data.

\section{Patient and public involvement}

Patients and the public were not involved in the design, conduct, reporting or dissemination plans of our research.

\section{Researcher characteristics and reflexivity}

Reflexivity was maintained by the research team through the analysis and writing by discussing and challenging established assumptions. The first author conducted all interviews and was not known to the participants of this research prior to undertaking this study.

\section{RESULTS}

\section{The context of universal healthcare in Spain pre-2012}

First, numerous interviewees discussed the importance of understanding the backdrop of the changes in 2012 and what a significant departure they were from existing legislation at the time. Prior to 2012, the Spanish system 
essentially provided universal healthcare for all, and this included irregular migrants, even if they were in the process of applying for health cards. The 2012 Royal Decree Law excluded undocumented migrants from healthcare with several exceptions, but even those exceptions were at times violated. This was demoralising for many healthcare workers, who had previously been very proud of their universal healthcare system.

Before health care [was changed], let's say from 2000 to 2012, anyone who was registered as a person in Spain had to be served in the public system... A person who did not work, as a person without resources...was a beneficiary of health care, just like a person who was a bank manager. $(007 \mathrm{~F})$

Several participants mentioned that the national health system before 2012 provided healthcare for everyone, but that after restrictions began in 2012, reversing these restrictions was challenging.

Till 2012, the Spanish laws and the will of the majority of health professionals was an attention that tended towards universality. [The system was] more and more universal until the appearance of a Royal Decree in 2012 that clearly broke that trend. (007 F)

Before the Decree of 2012, assistance was for everyone. It is a very open national health system. It all started from 2012, and when you go in one direction, going back is very difficult. (003 M)

\section{Erosion of trust in government}

Second, numerous subthemes emerged regarding the legislative barriers to providing healthcare to irregular migrants. Interviewees discussed an erosion of trust between the government and the people due to 'medical tourism,' which was used as a rationale for the more restrictive policies of 2012.

There is health tourism... but the problem is that health tourism is not practiced by people in an irregular situation. Health tourism is normally done by people with resources, with money, usually Europeans, belonging to the European Union... But not the people who come to Spain to work, and who come as irregular migrants... (006 M)

Participants reported that the government used the economic pretext of an unsustainable system to create this antimigrant policy, and that even the 2018 RDL was only 'lip service.'

The problem with the new Royal Decree is that, indeed, it was not very brave (poco valiente) to recognize that all irregular people who live effectively in Spain should have the same right to health care as a Spanish person. (006 M)

\section{Difficulty of proving 3-month residency requirement}

Third, most interviewees discussed how the 2018 Royal Decree Law theoretically was passed to provide much broader access to care, but the main restriction of the $2018 \mathrm{RDL}$ is that access to the public healthcare system is only available to residents (including irregular migrants) who are able to demonstrate that they have lived in Spain for at least 3 months. This 3-month residency requirement did not exist in the 2012 legislation. To some interviewees, the more progressive Royal Decree Law of 2018 appeared to be a false pretence that did not actually guarantee more access.

With regard to people who cannot demonstrate having been in Spain for 90 days, for those people, of course, the situation has worsened. (006 M)

Numerous respondents indicated that accessing care in cases of emergencies would generate an invoice if the migrant was unable to prove 3 months' residence, resulting in not only financial but potential further legal ramifications.

For example, if they tell you that they are going to do an operation for appendicitis, and when it ends they tell you: 'the procedure costs $€ 3,000$ ', and they create an invoice... from that moment you start to be delinquent. With which, you cannot open businesses, you cannot open an account in the bank, you cannot pay a mortgage... Through a system that exists in Spain, which is published in the Official Gazette of the Province, you remain in the delinquent registry... They don't give you credit cards, and when you want to get a job or open a business, you can't. (005 M)

If they invoice me and I cannot pay, I will be in permanent debt with the State and that will prevent me from going to get the papers in the future, and that is a problem. (006 M)

In addition, this 3-month requirement has been interpreted differently by various public officials and therefore has been implemented in an inconsistent manner.

The main barrier is the administrative one and the disparity of practices when applying the existing regulations. Because in each health center, they have... a person who is a social worker who must interpret that regulation. The regulations are interpreted in such a way that, from one health center to another, one social worker ... interprets that the person has to be registered in order to meet [the] three months [requirement], and others who say that [they can meet the three month requirement] with a Spanish entry stamp in their passport. (011 F)

\section{Areas of ambiguity for previously protected persons}

Several interviewees mentioned ambiguous cases that were not addressed in the change from the 2012 to 2018 legislation. Although the 2012 RDL was more restrictive than the previous system of universal healthcare, 
numerous respondents noted that at least it was clear that 5 classes of undocumented migrants were entitled to receive health care in any case: minors, pregnant women, those needing emergency care until medical discharge, victims of human trafficking, and asylum seekers. Respondents reported that the exemptions for these persons, however, were not mentioned in the 2018 RDL, Under the 2018 law, there was a lack of specific approval or denial of care for these populations.

The problem of 2018 is that it does not expressly say that minors, pregnant women, emergency care in any case are guaranteed, but neither does it deny it. So there is talk that people in an irregular situation need 90 days to settle in Spain, and that there are no exceptions... The problem is that, that the Royal Decree of 2018 from a legal point of view is what in Spain we would call 'a botch.' It leaves out important questions without being properly regulated, and that gives scope to broad and restrictive interpretations, and that is very dangerous, and more so in a context where there are autonomous communities where conservative governments supported by far-right parties are ruling. $(006 \mathrm{M})$

Respondents also reported that this lack of explicit regulations for protected populations in the 2018 RDL was often interpreted to mean that healthcare benefits were not available to these groups of people.

Even the previous regulations, Royal Decree 16/2012, which was a very exclusive Decree, did guarantee that in any case, and regardless of the time and all that, there were 5 situations in which every person in an irregular situation had access to the health care... Those 5 categories were entitled to receive health care... Although later, it is true, that in practice this law was violated many times, but at least on paper (in the law) that was recognized. (006 M)

Various respondents provided their own differing understandings and applications of the current law, with some commenting that the removal of the 2012 'emergency exceptions' has significantly affected migrants who cannot demonstrate 90 days of residence in Spain, including for emergencies.

This lack of clarity regarding entitlements added to existing barriers to care among migrants, such as fear of reporting and language barriers.

Generally speaking, someone is not expellable for [not] being registered. Still there is fear because, of course, when you are a foreigner, you do not know very well what your rights are, you do not have all the information. There are people who prefer, although they could register, they prefer to be hidden. (002 M)

Barriers, from our experience... one, now, is linguistics, and that is that many people who do not know the language, therefore, will not know what the chances are that someone who is in irregular situation will have health care or not. $(011 \mathrm{~F})$

\section{Jurisdictional authority and conflicts between national and autonomous community governments}

A fifth subtheme emerged of additional confusion about questions of jurisdictional authority and conflicts between the national government and the governments of the 17 autonomous communities.

In Spain there is a national health system, but in reality it is a collection of 17 regional health services. Why? Well, because they have full autonomy, and when I say full, it is full. In other words, the Ministry can say that it facilitates health care under certain conditions, and an Autonomous Community can say no.... (004 M)

States are allowed to prescribe healthcare policies as long as they do not contradict national laws. The case of the Valencian Autonomous Community was mentioned several times, where there was a Royal Decree of 2015 that guaranteed access to irregular migrants, essentially subverting the national 2012 restrictions. However, this was overturned by the National Supreme Court, resulting in additional confusion about which entitlements were available to irregular migrants. Interviewees also expressed sentiments about a need for the National Government to further clarify these entitlements and the practical application of the law.

In addition, many autonomous communities drew up their own regulations and interpretations of the law, and the AC a migrant lived in would determine if they had a certain healthcare right or not. If migrants moved to a different $\mathrm{AC}$, they would have to restart the process and potentially have different entitlements available to them.

It is true that this violation is not occurring in a comparable way between the different autonomous communities. There are autonomous communities that have continued to legislate so that these [exception populations] will be given health coverage. In most autonomous communities, in fact, legislation has been passed to allow this, but there are autonomous communities, especially where the most conservative parties govern... Madrid and Galicia in particular, where the opposite order has been given. The order has been given that if a pregnant woman cannot demonstrate that she has been in Spain for 3 months, she must be charged for healthcare, she cannot be given standard healthcare. (006 M)

It is a system that is enormously chaotic for something that would have been simpler to approve a comprehensive national regulation to guarantee and recognize that all people, regardless of the administrative situation they have, due to the mere fact of living in Spain, have the right to healthcare. (006 M) 
Near impossibility of obtaining documentation for exportation of healthcare

Respondents also discussed the administrative barriers faced by undocumented migrants in obtaining a health card, which was necessary to receive public healthcare. Specifically, the 2018 Royal Decree Law required undocumented residents coming from EU member countries to obtain documentation of exportability of healthcare. Respondents indicated that this requirement was nearly impossible to fulfil.

...The Royal Decree, in addition to requiring 90 days, people must also demonstrate that there is no third party required to pay... This means that... they do not have the right to receive health care in Spain from their country of origin... For example, the population that comes from Romania, the certificate that they have to present here in Spain is called the 'Certificate of Non-Exportation of the Right to Health Care,' which is a certificate that the Romanian Government has to give, and shows that, effectively, the Romanian Government does not cover the health care of the people who are here; it is not a certificate that can be obtained from Spain. People have to travel to Romania to obtain it, and there is also a fee. So, of course, people who are in an irregular situation, who are normally poor people... these are all added vulnerabilities, and they require a document that is very expensive to procure. We are advocating because the person should not have to obtain that document, and it must be the Spanish Administration itself that shows that this person has health care covered by another means. But one should not force a person who needs to receive health care to comply with a bureaucratic procedure that is very difficult to obtain and can be a barrier for them. (006 M)

\section{Difficulties obtaining necessary paperwork to prove residence (empadronamiento)}

An additional theme of the difficulty of obtaining the empadronamiento, or registration with the municipality of residence, was also mentioned by numerous respondents.

... Many undocumented immigrants do not have the possibility of accessing the registration because the fundamental requirement for registration is identification; many of these patients cannot be identified and when they go to your consulate or embassy to request identification or your passport, it is impossible to obtain it. Therefore, they are in a trap from which they cannot get out. (009 M)

Respondents living in temporary or unregistered dwellings reported difficulty providing proof of living in Spain and stated that they believed other proof of residency, such as school registration, should be recognised more universally across autonomous communities.
It is true that registration is an important barrier for people in an irregular situation because many of them cannot demonstrate living in the flat in which they live or living in situations of sub-housing. (006 M)

In addition, two respondents stated that even the appointment to become registered in some areas required a 2 to 3 month wait and therefore imposed a delay in the 3-month residency 'clock' if only an official registration was recognised as residency in Spain.

\section{Assistance from NGOs}

The last theme from many respondents was discussion of the need for more administrative and legal support for irregular migrants which, in the meantime, is being filled by numerous non-governmental organisations. Respondents commented on the advocacy of specific groups such as Yo Sí Sanidad Universal in Madrid, ODUSalud in Valencia, and that multiple regional networks including Doctors of the World (Médicos del Mundo) in different autonomous communities. REDER has been another group that has been used to coordinate advocacy work at the national level. These NGOs have been created over time to mobilise against health exclusion within specific regions, providing services such as direct liasions with the appropriate government ministries, accompanying patients with translators to social services and medical care appointments, and even actively pursuing litigation against the 2018 RDL.

We have a close collaboration with all the NGOs . We work with the Red Cross, which are usually the first to intervene with this type of person, but well, there is also UNHCR, Doctors Without Borders... with all these NGOs we collaborate closely. They even provide us with information on people who come from their country for reasons of political asylum, for conditions of political asylum, for international protection. They tell us which people are coming... (008 F)

...Even on many occasions, the NGO itself, depending on the origin of the patient... can supply translators to accompany the patient. (004 M)

\section{DISCUSSION}

Our study found that the 2018 Royal Decree Law was more progressive and inclusive in the healthcare entitlements provided to irregular migrants compared with its predecessor, the very restrictive 2012 Royal Decree Law, which had been demoralising for some healthcare workers and provided a backdrop of legal and administrative barriers that were difficult to change. However, respondents commented that there was a significant gap left in the treatment of pregnant women, minors, victims of human trafficking, asylum seekers, and those needing emergency care. Specifically, the 2012 RDL clearly stated that these were 5 categories of exceptions and that these persons would be provided healthcare; the 2018 law did not state whether these exceptions would be 
continued or were now denied. This gave rise to an unresolved legal ambiguity about when, and in which cases, undocumented migrants should be cared for. Many provisions of the 2018 RDL are still subject to interpretation by autonomous communities as well as local authorities. All of this exists in the backdrop of the constant struggle of authority between Autonomous Communities and the National Government.

One of the principal themes that emerged is that the RDL 2012 triggered changes that were very difficult to reverse even after the passage of the RDL 2018. There appeared to be general consensus that while the RDL 2018 has a 'beautifully written preamble' that defends the right to universal health care, it has a lack of legal clarity regarding conditions on how to exercise those rights and has been written in such a way that 'open[s] the door to exclusion again' $(007 \mathrm{~F})$. This lingering impact the RDL 2012 has made on current law is relevant to the global context of how countries legislate entitlements.

These findings do not appear to be widely known in academic or published literature, although the reports of Spanish NGOs such as REDER, ODUSalud, and Yo Sí Sanidad have documented violations of the 2018 RDL and continue to advocate for more universal inclusion of healthcare for all persons living in Spain. This study builds on existing qualitative interview studies of the impact of NGOs such as REDER on the social activation of citizens against the 2012 RDL by demonstrating the impact NGOs have had on the transition to the $2018 \mathrm{RDL}^{44}$ Furthermore, other literature has documented the historical context of legislation related to healthcare access in Spain, showing that the RDL $16 / 2012$ was a clear departure from previous legislation. ${ }^{22}$ Spanish autonomous communities' disparate application of the national law regarding healthcare entitlements has also been cited in previous literature. ${ }^{22}{ }^{28}$ This is supported by our findings suggesting that the legal ambiguities of the provisions stated in the RDL 2018 exacerbate the inevitable deviations in application of a national law and produce even greater departures from the intended law. Our findings also contribute to the current body of knowledge by revealing insights into the situations encountered by a diverse sample of healthcare workers, government officials, and members of advocacy organisations who are most closely involved with the provision of healthcare for undocumented migrants in Spain. In doing so, this study reveals the impact of not only legal, administrative regulation, but also the way in which the application of these regulations translates into real access to healthcare for irregular migrants.

The gap between the international human rights framework and legislation surrounding health entitlements for irregular migrants has been well documented. ${ }^{534}{ }^{45-57}$ Our findings also support other work that has identified administrative complexities as well as stakeholders' lack of awareness of legal entitlements (stakeholders include providers, administrative staff, and migrants themselves). ${ }^{44} 58$ Prior work has shown that irregular migrants tend to underuse healthcare, and this may be due to barriers that we found in this study, including administrative requirements, lack of knowledge regarding entitlements, fear of reporting and discrimination. ${ }^{59-61}$ This study adds to the literature on administrative complexities and lack of stakeholder awareness by demonstrating that the culminating effects of both legal and administrative barriers work collectively to further intensify the lack of access to care among undocumented migrants in Spain. Our findings are also supported by studies that have indicated that the use of the Spanish healthcare system by immigrants is not higher than that by the local population, suggesting that there is little incentive to restrict irregular migrants' access to healthcare. ${ }^{21}$

The findings of this investigation also demonstrate that, whether intentionally or not, the RDL 2018 has legally guaranteed access for those undocumented migrants who can prove residence in Spain for more than 3 months while leaving the status of entitlements of certain vulnerable groups in question and subject to variable interpretation. Women, in particular, appear to be particularly vulnerable to these gaps in legislation. Overall, such vulnerabilities for undocumented migrants may be exacerbated in the face of global health crises, such as the coronavirus pandemic, for marginalised communities that already live on the fringes of society, who face additional challenges ranging from decreased social services and border closures to poverty and xenophobia. ${ }^{62}$ The policy implications of these findings include the need for clearer definitions of the entitlements of pregnant women, minors, victims of human trafficking, asylum seekers, and those needing emergency care; the reduction of administrative burden to prove residency; and the elimination of the requirement to produce documents of non-exportation of the right to healthcare for EU countries-such as Romania-which are known not to provide financial coverage of healthcare expenditures for their citizens that have moved elsewhere.

There are several important limitations to our study that could be addressed in future publications. First, we had a limited number of respondents which could be interpreted as a limitation as it can limit the diversity of perspectives in a body of work. However, our method of choosing the number of respondents was based on the principle of saturation, where additional interviews do not yield additional themes, data, or insight for the work. ${ }^{63}$ The idea of saturation originates in grounded theory and is often considered the 'gold standard' in qualitative inquiry. ${ }^{41}{ }^{64}$ Additionally, while the interviews were conducted in Spanish, they were later transcribed and translated into English. Misunderstandings may have occurred due to cultural differences during interpretation of the transcribed interviews. Finally, our study sample was comprised of healthcare workers and other individuals working in Spain, a country with its own, distinct healthcare system, and our results may not be generalisable to other European countries.

\section{CONCLUSION}

While Spain's current legislative environment allows for the provision of healthcare to irregular immigrants, the restrictions regarding proof of residency and lack of both 
legal and administrative clarity have created barriers to wider use of these benefits. The reversal of directionfrom a very inclusive policy of universal access prior to 2012 , to then a more restrictive policy promulgated in 2012, and then back to a more inclusive one in 2018-has made it difficult for the system to adapt, creating seeds of discontent and even mistrust of the national government.

Acknowledgements The authors are indebted to all the participants of the study who made this project possible. We would also like to recognize Javier Ortega Fernández, PhD for his technical assistance, with whom both authors verified the underlying data. The authors also acknowledge and thank Riham Alwan, MD, MPH and Heather Leutwyler, RN, PhD, for their input on the interview guide, and Stefany Zagorov for editorial assistance.

Contributors Concept and design; qualitative analysis; administrative, technical, or material support; supervision: both authors. Acquisition, analysis or interpretation of data, drafting of the manuscript, obtained funding: RYH. Critical revision of the manuscript for important intellectual content: DG-G.

Funding This project was partially supported by the University of California San Francisco; National Center for Advancing Translational Sciences, National Institutes of Health, through UCSF-CTSI Grant Number UL1 TR001872; and the FulbrightSchuman Program. Its contents are solely the responsibility of the authors and do not necessarily represent the official views of any of the sponsors.

Competing interests The authors declare that the research was conducted in the absence of any commercial or financial relationships that could be construed as a potential conflict of interest.

Patient consent for publication Not required.

Ethics approval Ethical approval for this study was obtained from the Ethics Committee of the Universidad de Alicante (UA2019-12-17). Each participant gave informed consent. Participants did not receive any monetary compensation.

Provenance and peer review Not commissioned; externally peer reviewed.

Data availability statement No data are available. Data collected for this study will not be made available to others given confidentiality of the interviews.

Supplemental material This content has been supplied by the author(s). It has not been vetted by BMJ Publishing Group Limited (BMJ) and may not have been peer-reviewed. Any opinions or recommendations discussed are solely those of the author(s) and are not endorsed by BMJ. BMJ disclaims all liability and responsibility arising from any reliance placed on the content. Where the content includes any translated material, BMJ does not warrant the accuracy and reliability of the translations (including but not limited to local regulations, clinical guidelines, terminology, drug names and drug dosages), and is not responsible for any error and/or omissions arising from translation and adaptation or otherwise.

Open access This is an open access article distributed in accordance with the Creative Commons Attribution Non Commercial (CC BY-NC 4.0) license, which permits others to distribute, remix, adapt, build upon this work non-commercially, and license their derivative works on different terms, provided the original work is properly cited, appropriate credit is given, any changes made indicated, and the use is non-commercial. See: http://creativecommons.org/licenses/by-nc/4.0/.

ORCID iD

Renee Y Hsia http://orcid.org/0000-0001-9819-6926

\section{REFERENCES}

1 European Parliament. European parliament resolution of 8 March 2011 on reducing health inequalities in the EU. 2011;2010/2089(INI). Available: https://www.europarl.europa.eu/sides/getDoc.do? pubRef=-//EP//TEXT+TA+P7-TA-2011-0081+0+DOC+XML+V0//EN [Accessed 25 Jun 2020].

2 European Parliament. European parliament resolution of 4 July 2013 impact of the crisis on access to care for vulnerable groups. 2013; 2013/2044(INI). Available: https://www.europarl.europa.eu/sides/ getDoc.do?type=TA\&language $=E N \&$ reference $=P 7-T A-2013-328$ [Accessed 25 Jun 2020].

3 United National Human Rights Office of the High Commissioner. On economic, social and cultural rights, 1976. Available: https://www.
ohchr.org/EN/Professionallnterest/Pages/CESCR.aspx [Accessed 25 Jun 2020].

4 European Convention. Charter of fundamental rights of the European Union. Off J Eur Communities $2000 \mathrm{https}$ ://eur-lex.europa.eu/legalcontent/EN/TXT/?uri=CELEX:12012P/TXT

5 European Union Agency for Fundamental Rights. Fundamental rights of migrants in an irregular situation in the European Union: comparative report, 2011. Available: https://fra.europa.eu/en/ publication/2012/fundamental-rights-migrants-irregular-situationeuropean-union [Accessed 25 Jun 2020].

6 European Centre for Disease Prevention and Control. Public health guidance on screening and vaccination for infectious diseases in newly arrived migrants within the EU/EEA, 2018. Available: https:// www.ecdc.europa.eu/en/publications-data/public-health-guidancescreening-and-vaccination-infectious-diseases-newly [Accessed 29 Apr 2021].

7 Ingleby D. Moving upstream: changing policy scripts on migrant and ethnic minority health. Health Policy 2019;123:809-17.

8 World Health Organization, The UN Refugee Agency. Toolkit for assessing health system capacity to manage large influxes of refugees, asylum-seekers and migrants, 2016. Available: https:// www.euro.who.int/en/publications/abstracts/toolkit-for-assessinghealth-system-capacity-to-manage-large-influxes-of-refugees,asylum-seekers-and-migrants-2016 [Accessed 25 Jun 2020].

9 International Organization for Migration. Migration flows to Europe: 2017 overview. Displacement tracking matrix, 2018. Available: https://migration.iom.int/reports/europe-\%E2\%80\%94-mixedmigration-flows-europe-yearly-overview-2017 [Accessed 25 Jun 2020].

10 International Organization for Migration. Migration flows - Europe. Available: https://migration.iom.int/europe?type=arrivals [Accessed 25 Jun 2020].

11 Kern S. Europe: migrant crisis reaches Spain. International Policy Council, Gatestone Institute, 2017. https://www.gatestoneinstitute. org/10840/spain-migrant-crisis

12 Fanjul G, Gálvez I, Zuppiroli J. Crecer sin Papeles en España. Save the Children España 2021;52 https://porcausa.org/wp-content/ uploads/2021/02/Infancia_sin_papeles_en_Espana.pdf

13 Platform for International Cooperation on Undocumented Migrants. Undocumented migrants and the Europe 2020 strategy: making social inclusion a reality for all migrants in Spain, 2015. Available: http://picum.org/wp-content/uploads/2017/11/UndocumentedMigr antsandEurope2020Strategy_EN.pdf

14 Legido-Quigley H, Pajin L, Fanjul G, et al. Spain shows that a humane response to migrant health is possible in Europe. Lancet Public Health 2018;3:e358.

15 Cortes Generales. The Spanish constitution, 1978. Available: https:// www.boe.es/legislacion/documentos/ConstitucionINGLES.pdf [Accessed 25 Jun 2020].

16 Bernal-Delgado E, García-Armesto S, Oliva J, et al. Spain: health system review. Health Syst Transit 2018;20:1-179 https://www.euro. who.int/_data/assets/pdf_file/0008/378620/hit-spain-eng.pdf

17 The National Statistics Institute. Basic demographic indicators: latest data. ine. Available: https://www.ine.es/dyngs/INEbase/en/operacion. htm?c=Estadistica_C\&cid=1254736177003\&menu=ultiDatos\&idp= 1254735573002 [Accessed 18 Aug 2020].

18 Eurostat. Immigration law enforcement in the EU - figures for 2019. Eurostat: your key to European statistics, 2020. Available: https://ec. europa.eu/eurostat/web/products-eurostat-news/-/DDN-20200722-1 [Accessed 18 Aug 2020].

19 Pew Research Center. Europe's unauthorized immigrant population peaks in 2016, then levels off. pew research center's global attitudes project. Available: https://www.pewresearch.org/global/2019/11/13/ europes-unauthorized-immigrant-population-peaks-in-2016-thenlevels-off/ [Accessed 18 Aug 2020].

20 Frontex. Migratory routes: Western Mediterranean route. Available: https://frontex.europa.eu/along-eu-borders/migratory-routes/ western-mediterranean-route/ [Accessed 18 Aug 2020].

21 Lostao L, Ronda E, Pascual C, et al. Erosion of universal health coverage and trend in the frequency of physician consultations in Spain. Int J Equity Health 2020;19:121.

22 Suess A, Ruiz Pérez I, Ruiz Azarola A, et al. The right of access to health care for undocumented migrants: a revision of comparative analysis in the European context. Eur J Public Health 2014;24:712-20.

23 Chiarenza A, Dauvrin M, Chiesa V, et al. Supporting access to healthcare for refugees and migrants in European countries under particular migratory pressure. BMC Health Serv Res 2019;19:513.

24 Norredam M, Mygind A, Krasnik A. Access to health care for asylum seekers in the European Union--a comparative study of country policies. Eur J Public Health 2006;16:285-9. 
25 Bozorgmehr K, Razum O. Effect of restricting access to health care on health expenditures among asylum-seekers and refugees: a quasi-experimental study in Germany, 1994-2013. PLoS One 2015;10:e0131483.

26 Woodward A, Howard N, Wolffers I. Health and access to care for undocumented migrants living in the European Union: a scoping review. Health Policy Plan 2014;29:818-30.

27 Beck TL, Le T-K, Henry-Okafor Q, et al. Medical care for undocumented immigrants: national and international issues. Prim Care 2017;44:e1-13

28 Cimas M, Gullon P, Aguilera E, et al. Healthcare coverage for undocumented migrants in Spain: regional differences after Royal decree law 16/2012. Health Policy 2016;120:384-95.

29 Cuadra CB6. Policies on health care for Undocumented migrants in EU27, country report, Spain. Sweden; 2010. https://citeseerx.ist.psu. edu/viewdoc/download?doi=10.1.1.888.4774\&rep=rep1\&type=pdf

30 Gray BH, van Ginneken E. Health care for undocumented migrants: European approaches. Issue Brief 2012;33:14.

31 Scholz N. The public health dimension of the European migrant crisis. Eur Parliam Res Serv 2016;8.

32 World Health Organization. Report on the health of refugees and migrants in the WHO European region: no public health without refugee and migrant health, 2018. Available: http://www.euro.who. int/en/publications/html/report-on-the-health-of-refugees-andmigrants-in-the-who-european-region-no-public-health-withoutrefugee-and-migrant-health-2018/en/index.html [Accessed 10 Dec 2019].

33 Rodriguez N. Undocumented migration and evolving health care ethical issues. Am J Bioeth 2019;19:58-60.

34 European Union Agency for Fundamental Rights. Migrants in an irregular situation: access to healthcare in 10 European Union Member States, 2011.

35 Ritchie J, Lewis J, Lewis P. Qualitative research practice: a guide for social science students and researchers. Sage, 2013.

36 Turner DW III. Qualitative interview design: a practical guide for novice Investigators. Qual Rep;15:754-60.

37 Jamshed S. Qualitative research method-interviewing and observation. J Basic Clin Pharm 2014;5:87-8.

38 Jansen $\mathrm{H}$. The logic of qualitative survey research and its position in the field of social research methods. Forum Qual Sozialforschung Forum Qual Soc Res 2010;11.

39 Kallio H, Pietilä A-M, Johnson M, et al. Systematic methodological review: developing a framework for a qualitative semi-structured interview guide. J Adv Nurs 2016;72:2954-65.

40 Morgan MG. Risk communication. 1st edn. Cambridge University Press, 2005.

41 Guest G, Bunce A, Johnson L. How many interviews are enough? an experiment with data saturation and variability. Field Methods 2006;18:59-82.

42 Francis $\mathrm{JJ}$, Johnston M, Robertson $\mathrm{C}$, et al. What is an adequate sample size? Operationalising data saturation for theory-based interview studies. Psychol Health 2010;25:1229-45.

43 Braun V, Clarke V. Using thematic analysis in psychology. Qual Res Psychol 2006;3:77-101.

44 Urtaran-Laresgoiti M, Fonseca Peso J, Nuño-Solinís R. Solidarity against healthcare access restrictions on undocumented immigrants in Spain: the REDER case study. Int J Equity Health 2019;18:82.

45 Karl-Trummer U, Novak-Zezula S. Health care in NowHereLand improving services for Undocumented migrants in the EU. ViennaCentre for Health and Migration, 2010. https://www.brighton. ac.uk/research-and-enterprise/groups/healthcare-practice-andrehabilitation/research-projects/nowhereland.aspx

46 Cuadra CB. Right of access to health care for undocumented migrants in EU: a comparative study of national policies. Eur J Public Health 2012;22:267-71.
47 Dauvrin M, Lorant V, Sandhu S, et al. Health care for irregular migrants: pragmatism across Europe: a qualitative study. BMC Res Notes 2012;5:99.

48 European Centre for Disease Prevention and ControlNoori T. Migrant health access to HIV prevention, treatment and care for migrant populations in EU/EEA countries, 2011. Available: https://www.ecdc. europa.eu/sites/portal/files/media/en/publications/Publications/ 0907_TER_Migrant_health_HIV_Access_to_treatment.pdf

49 ELIAMEP, Hellenic Foundation for European and Foreign Policy, Triandafyllidou A, CLANDESTINO. Undocumented migration: counting the uncountable. data and trends across Europe. final report.

50 Collantes S, Health for Undocumented Migrants and Asylum seekers. Access to health care for Undocumented migrants and asylum seekers in $10 \mathrm{EU}$ countries: law and practice. HUMA Network 2009.

51 Collantes S, Soler A, et al, Health for undocumented migrants and asylum seekers network. Access to healthcare and living conditions of asylum seekers and Undocumented migrants in Cyprus, Malta, Poland and Romania. Médecins du monde 2011.

52 Guerreiro AIF, Navarro AA, Vergara R. Ensuring the right of migrant children to healthcare: the response of hospitals and health services. International Organization of Migration, 2009.

53 Pace P, Shapiro S, International Organization of Migration (IOM). Migration and the right to health in Europe. Available: https:// webgate.ec.europa.eu/chafea_pdb/assets/files/pdb/2006347/ 2006347_right_to_health_background_paper.pdf [Accessed 10 Dec 2020].

54 Chauvin P, Parizot I, Médecins du Monde (Doctors of the World), European Observatory on Access to Health Care. Access to healthcare for undocumented migrants in 11 European countries. Médecins du Monde 2009;154 https://www.hal.inserm.fr/inserm00419971

55 Chauvin P, Simonnot N, Médecins du Monde (Doctors of the World). Access to health care for vulnerable groups in the European Union in 2012. Médecins du Monde 2012 https://www.hal.inserm.fr/inserm00695827

56 Bicocchi L, LeVoy M, Platform for International Cooperation on Undocumented Migrants (PICUM). Undocumented children in Europe: invisible victims of immigration restrictions. platform for international cooperation on Undocumented migrants (PICUM), 2009.

57 Geddie E, LeVoy M, Platform for International Cooperation on Undocumented Migrants (PICUM). PICUM's main concerns about the fundamental rights of undocumented migrants in Europe, 2009. Available: https://documentation.lastradainternational.org/doccenter/2284/picums-main-concerns-about-the-fundamental-rightsof-undocumented-migrants-in-europe

58 Vázquez M-L, Vargas I, Jaramillo DL, et al. Was access to health care easy for immigrants in Spain? The perspectives of health personnel in Catalonia and Andalusia. Health Policy 2016;120:396-405.

59 Gimeno-Feliu LA, Pastor-Sanz M, Poblador-Plou B, et al. Overuse or underuse? Use of healthcare services among irregular migrants in a north-eastern Spanish region. Int J Equity Health 2021;20:41.

60 Kvamme E, Ytrehus S. Barriers to health care access among undocumented migrant women in Norway. Soc Health Vulnerability 2015;6:28668.

61 Hacker K, Anies M, Folb BL, et al. Barriers to health care for undocumented immigrants: a literature review. Risk Manag Healthc Policy 2015;8:175-83.

62 World Health Organization. ApartTogether survey: preliminary overview of refugees and migrants self-reported impact of Covid-19, 2020. Available: https://www.who.int/publications/i/item/ 9789240017924

63 Charmaz K. Constructing grounded theory. Sage Publications, 2006.

64 Fusch P, Ness L. Are we there yet? Data saturation in qualitative research. Qual Rep 2015;20:1408-16. 